\title{
Green turtle Chelonia mydas mixed stocks in the western South Atlantic, as revealed by mtDNA haplotypes and drifter trajectories
}

\author{
M. C. Proietti ${ }^{1, *}$, J. W. Reisser ${ }^{1,3}$, P. G. $\operatorname{Kinas}^{4}$, R. $\operatorname{Kerr}^{2}$, D. S. Monteiro6 ${ }^{6}$ L. F. Marins ${ }^{5}$, \\ E. R. Secchi ${ }^{1}$ \\ ${ }^{1}$ Laboratório de Tartarugas e Mamíferos Marinhos, and ${ }^{2}$ Laboratório de Estudos dos Oceanos e Clima, \\ Instituto de Oceanografia, Universidade Federal do Rio Grande (FURG), Rio Grande, RS 96201-900, Brazil \\ ${ }^{3}$ School of Environmental Systems Engineering and the UWA Oceans Institute, University of Western Australia, Perth, \\ Western Australia 6009, Australia \\ ${ }^{4}$ Laboratório de Estatística Ambiental, Instituto de Matemática, Estatística e Física and ${ }^{5}$ Laboratório de Biologia Molecular, \\ Instituto de Ciências Biológicas, FURG, Rio Grande, RS 96201-900, Brazil \\ ${ }^{6}$ Núcleo de Educação e Monitoramento Ambiental (NEMA), Rio Grande, RS 96207-480, Brazil
}

\begin{abstract}
Genetic structure and natal origins of green turtle mixed stocks in southern Brazil were assessed based on analyses of mtDNA control region sequences from the Arvoredo Island $(\mathrm{n}=115)$ and Cassino Beach $(\mathrm{n}=101)$ feeding areas. These were compared to other mixed aggregations to examine structuring, and to Atlantic Ocean nesting colonies to evaluate natal origins through Bayesian mixed stock analysis (MSA). In order to develop novel priors, surface drifter trajectories in the Atlantic were analyzed and combined with rookery data, and we used KulbackLeibler information measures in order to compare the difference of information among the 4 proposed priors. Each study area presented 12 haplotypes, 10 of which were shared at similar frequencies. Haplotypes CM-A8 and CM-A5 represented $\sim 60$ and $20 \%$, respectively, and remaining haplotypes accounted for $<5 \%$ of samples. The 2 study areas were genetically similar to all feeding grounds in the western South Atlantic except Almofala, in northeast Brazil, and genetically different from Caribbean and North American mixed stocks. Drifter trajectory analysis revealed that drifters from Ascension and Trindade Islands have a larger chance of reaching Brazil. The priors drifter data and rookery size/drifter data combined contained the most information, but stock estimates were not greatly changed. MSA indicated that Ascension, Aves/Surinam and Trindade were the main stock contributors to the study areas. Since impacts on mixed stocks may affect populations thousands of $\mathrm{km}$ away, the results presented here have important implications for the conservation of this endangered species.
\end{abstract}

KEY WORDS: Green turtle $\cdot$ Feeding grounds $\cdot$ South Brazil $\cdot$ Genetic structure $\cdot$ Natal origins · Dispersal patterns

Resale or republication not permitted without written consent of the publisher

\section{INTRODUCTION}

The globally distributed and endangered green turtle Chelonia mydas occupies various ecological niches throughout its life cycle (Meylan \& Meylan 1999, Bolten 2003). A general life pattern encom- passes (1) a juvenile oceanic phase, in which it is believed that young turtles drift following major surface ocean currents; (2) a subsequent neritic phase, when animals reach a certain size and recruit to coastal foraging grounds; and (3) large-scale migrations between foraging and breeding areas upon sex- 
ual maturity (Bolten 2003). Short or long-range movements between foraging grounds are also observed (Godley et al. 2003). The complexity of this life cycle and the large geographical/temporal distances require indirect research, such as molecular analyses, which can help elucidate many aspects of sea turtle life history, including population structure, phylogeography, systematics, natal origins and natal homing (Avise 2007).

Natal homing, in which female turtles return to their birth site to reproduce, was first hypothesized by Carr (1967) based on the observation that female green turtles are phylopatric, that is, they return to nesting sites (rookeries) at varying degrees of precision throughout subsequent nesting cycles (Carr 1967, Miller 1997, Formia et al. 2007, Lee et al. 2007). Despite the difficulty in testing this hypothesis, genetic studies have supported that rookeries are structured in terms of mtDNA haplotypes, while foraging areas present overlapping haplotypes (Bowen \& Karl 2007). Due to this structure between rookeries, a Bayesian statistical approach known as mixed stock analysis (MSA) can be applied to determine contributions of rookeries (stocks) to mixed sea turtle foraging aggregations (mixed stocks), employing differences and similarities in relative frequency of haplotypes to link mixed stocks to their sources (Pella \& Masuda 2001), providing insight on the origins of animals at foraging areas.

The relevance of identifying natal origins of mixed stocks for conservation lies in the fact that rookeries, despite being generally independent reproductively, are linked at the non-reproductive phases of the green turtle life cycle (Avise 2007). Therefore, impacts at foraging grounds and migratory routes may affect many breeding stocks, as well as other feeding areas, at different levels. Understanding these origins, as well as determining possible migratory routes, is crucial for the elaboration of management and conservation plans (Avise 2007, Bowen \& Karl 2007). MSA nevertheless has limitations, most notably in the adequate description of source populations, and estimates should be interpreted cautiously and preferably along with other data. An advantage of the Bayesian approach to MSA is the possibility of incorporating relevant prior information for improving the analytical model. Ecological data such as nesting population size and distance from source to mixture are common priors employed in sea turtle MSA, assuming that foraging ground composition is related to these factors. (e.g. Okuyama \& Bolker 2005, Bass et al.
2006, Naro-Maciel et al. 2007, Bolker et al. 2007, Monzón-Argüello et al. 2010). Nonetheless, the influence of priors on posterior inferences depend on the quality of analyzed data; when data is strong and large sample sizes are available, prior distributions will have minor effects on posterior estimates (Gelman et al. 2004).

The role of ocean currents in sea turtle dispersal has been thoroughly discussed (Luschi et al. 2003a). Hatchlings are considered by most authors as pelagic, dispersing almost passively with ocean currents until recruiting to coastal environments (Bolten 2003), and recent studies have attempted to describe this dispersion using surface drifters and current modeling. Parallels between ocean currents and MSA have been made for mixed stocks of green, loggerhead and hawksbill turtles in all oceans (e.g. Luke et al. 2004, Bass et al. 2006, Carreras et al. 2006, Blumenthal et al. 2009, Boyle et al. 2009, Godley et al. 2010, Jensen 2010, Monzón-Argüello et al. 2010); all these studies conclude that the compositions of mixed stocks depend on major and minor current systems. The description of sea turtle dispersal based on surface drifter tracks has long been proposed (e.g. Hays \& Marsh 1997) and is becoming increasingly applicable due to extensive efforts in drifter research and the large volume of available data in public online drifter databases. Surface drifters, accepted as good proxies of sea surface currents patterns, may give indications of the general influence of currents on early life stage dispersal routes, and could determine a prior for MSA of sea turtle populations worldwide.

Foraging ground composition, population connectivity and dispersal patterns have recently been considered priority research areas for sea turtle conservation (Hamann et al. 2010). In this context, this study aimed to (1) determine genetic differences amongst 2 southern Brazil foraging areas and other studied mixed aggregations in the Atlantic; (2) estimate contributions of different rookeries to the 2 mixed stocks; and (3) apply novel priors in Bayesian MSA using rookery and drifter information.

\section{MATERIALS AND METHODS}

\section{Tissue sampling}

Samples were collected from immature green turtles around Arvoredo Island $\left(27^{\circ} 51^{\prime} \mathrm{S}, 48^{\circ} 26^{\prime} \mathrm{W}\right)$, Santa Catarina state $(\mathrm{n}=66)$, and along the southern Rio Grande do Sul state coast $\left(31^{\circ} 21^{\prime} \mathrm{S}, 51^{\circ} 02^{\prime} \mathrm{W}\right.$ 
to $\left.33^{\circ} 44^{\prime} \mathrm{S}, 53^{\circ} 22^{\prime} \mathrm{W}\right)(\mathrm{n}=101)$, Brazil. For simplification, the latter will hereafter be referred to as Cassino Beach (CB). Arvoredo Island (AI) lies within the Arvoredo Marine Biological Reserve and presents rocky shores with diverse benthic organisms and a large population of green turtles (Reisser et al. 2008). $C B$ is an extensive and continuous sandy beach with few substantial hard substrates, such as the 2 jetties that protect the access canal to the Rio Grande Port in the Patos Lagoon estuary, which are built of granite rocks and present relatively high algae density (Coutinho \& Seeliger 1984). Immature green turtles are frequently found stranded along CB due to bycatch mortality, especially in warmer months (Monteiro et al. 2006). At AI, skin samples were collected using $5 \mathrm{~mm}$ disposable biopsy punches from the flippers of live individuals handcaptured during snorkeling and SCUBA dives carried out from July 2005 to April 2008. At CB, samples were collected using disposable scalpels from stranded live animals or carcasses found washed ashore during beach surveys conducted from January 2005 to May 2007. To avoid resampling, live animals were tagged with inconel tags provided by Projeto Tamar-ICMBio, and carcasses at CB were marked with spray paint. Samples were conserved in absolute ethanol and maintained at $-20^{\circ} \mathrm{C}$ until DNA extraction. Immature sea turtle sizes ranged from 33.5 to $83 \mathrm{~cm}$ (mean and SD: $50.2 \pm 10.04 \mathrm{~cm}$ ) and 29 to $71.5 \mathrm{~cm}(40.2 \pm 6.07 \mathrm{~cm})$ curved carapace length (CCL), respectively for $\mathrm{AI}$ and $\mathrm{CB}$, with significant difference in size between areas detected through a $t$-test $(\mathrm{p}<0.05)$.

\section{Laboratory procedures}

Tissue samples were macerated using conicalshaped grinders in a Tris- $\mathrm{HCl}$ lysis buffer containing Proteinase $\mathrm{K}$, and kept at $37^{\circ} \mathrm{C}$ until complete digestion. DNA was extracted through DNA Extraction Kits (Bioamerica) or standard phenol:chloroform procedure (adapted from Hillis et al. 1996). Approximately 500 bp-fragments of the mtDNA control region were amplified using primers LTCM1 and HDCM1 via PCR with conditions following Allard et al. (1994), or LTCM2 and HDCM2 (longer versions of the prior primers) with conditions following Lahanas et al. (1994). Illustra GFX purification kits (GE Healthcare) were employed for purification, and samples were sequenced in both directions using DYEnamic ET dye terminator kits in a MegaBACE 500 DNA sequencer (GE Healthcare).

\section{Data analysis}

mtDNA sequences

Sequences of $491 \mathrm{bp}$ were aligned using the software CLUSTAL_X 1.83 (Thompson et al. 1997), and haplotypes classified according to the Archie Carr Center for Sea Turtle Research online genetic bank (University of Florida, http://accstr.ufl.edu/genetics. $\mathrm{html})$. Additional sequences for AI ( $\mathrm{n}=49$; Proietti et al. 2009) were included in the analyses, totaling 115 samples. In order to verify differences between the study areas and other previously described Atlantic foraging grounds, exact tests of differentiation were conducted employing a Markov Chain Monte Carlo (MCMC) with 10000 steps and 1000 burn-ins, using Arlequin 3.11 (Excoffier et al. 2005). This software was also used to calculate pairwise $\Phi$-statistics for an analysis of molecular variance (AMOVA) with 10000 permutations and using the Kimura-2P model of nucleotide substitution as determined by jModelTest (Posada 2008). The Brazilian foraging grounds included in these analyses for comparative purposes were Ubatuba (SP), Almofala (CE) (Naro-Maciel et al. 2007), Rocas Atoll (RN) and Fernando de Noronha (PE) (Bjorndal et al. 2006). The last 2 were clumped for all analyses due to geographic proximity $(\sim 150 \mathrm{~km})$, small sample sizes and genetic similarity, following Bjorndal et al. (2006), and will hereafter be referred to as Rocas/Noronha. Other feeding areas in the Caribbean and North Atlantic were considered for comparison (see Fig. 1). Genetic structure patterns among study areas were taken into account when defining certain aspects of analyses of surface drifter data and MSA (see details below).

\section{Surface drifter trajectories and natal origins}

In order to develop 2 novel priors for MSA analysis, surface drifter data available for the Atlantic and Mediterranean (5842 drifters, February 1989 to January 2009) were downloaded from NOAA's Global Drifter Program (www.aoml.noaa.gov/envids/ gld). The number of drifters that passed through the nesting areas considered in the natal origin analyses and reached a target area in the eastern coast of Brazil was determined. The northern part of the Brazilian coast was not included due to evidence of genetic structuring between this area and the East Brazil coast (described in 'Results: Genetic differentiation'). Based on these data, a Bayesian framework was used to calculate the probability that a drifter 
that reached the target area is from a determined rookery (see Appendix 1).

The nesting areas considered as possible sources correspond to the rookeries in the Atlantic and Mediterranean with mtDNA characterization, as shown in Fig. 1. We highlight that the 2 African rookeries at Bioko and at São Tomé and Príncipe were grouped in all analyses due to proximity and genetic similarity, and are referred to as Gulf of Guinea (Bolker et al. 2007). Areas with an extent of $4^{\circ} \times 4^{\circ}$ (latitude and longitude) were delineated around all considered rookeries. In the case of insular rookeries, the area was designed with the island as a centerpoint; when the rookery was non-insular, the largest possible oceanic area directly next to land was selected. Although Aves Island and Surinam were considered separately in this step due to geographic distance, these rookeries and their respective genetic data were combined for natal origin analysis due to small sample sizes and genetic similarity (following Luke et al. 2004).

Probable natal origins were determined employing mtDNA data from the study areas and all possible sources (same rookeries used in surface drifter analysis) through Bayesian MSA implemented with software Bayes (Pella \& Masuda 2001). The study areas were also grouped, due to geographic proximity $(\sim 740 \mathrm{~km})$ and genetic similarity (this study), and 4 MSAs were performed considering openminded Dirichlet priors (i.e. parameters adding up to 1) with equally-weighed parameters ('uninformative' $\mathrm{MSA}_{1}$ ) and prior parameters weighed according to (1) number of females $\mathrm{yr}^{-1}$ in each source $\left(\mathrm{MSA}_{2}\right)$; (2) surface drifter data $\left(\mathrm{MSA}_{3}\right)$; and (3) a combination of both $\left(\mathrm{MSA}_{4}\right)$ (see Appendix 1). One MCMC was implemented for each rookery (a total of 10 chains, each starting overdispersed at 0.95 for the rookery being analyzed) in each analysis, with chain lengths varying from 10000 to 30000 , according to the Gelman-Rubin convergence factor (maintained under 1.2, and in most cases presented values of $\sim 1.0$, indicating convergence) and one-half chain length discarded as 'burn-in' steps (Pella \& Masuda 2001). We used Kulback-Leibler distances (Burnham \& Anderson 1998) in order to compare the difference of information among the 4 proposed priors. See Appendix 1 for additional remarks on this test.

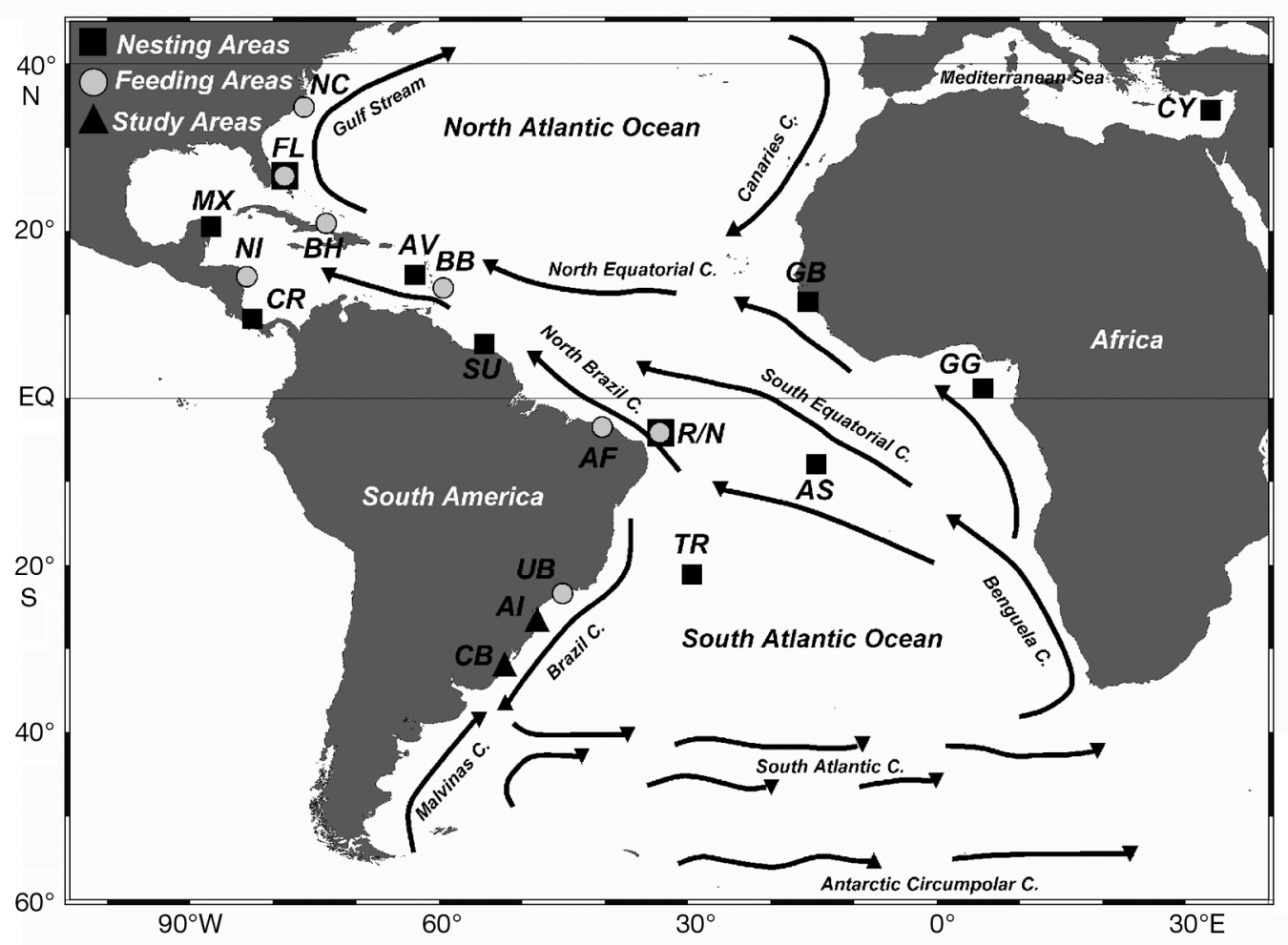

Fig. 1. General circulation pattern for the Atlantic Ocean (following Stramma \& England 1999), with study areas (ム), all compared rookeries (অ), and foraging areas (O). The following site abbreviations are used: Cassino Beach (CB), Arvoredo Island (AI), Ubatuba (UB), Almofala (AF), Rocas/Noronha (R/N), Ascension Island (AS), Trindade Island (TR), Guinea Bissau (GB), Gulf of Guinea (GG), Aves Island (AV), Mexico (MX), Costa Rica (CR), Surinam (SU), Florida (FL), Cyprus (CY), Barbados (BB), Bahamas (BH), Nicaragua (NI), North Carolina (NC). C.: current 


\section{RESULTS}

\section{Haplotype frequencies and genetic diversity}

Each study area presented 12 previously described haplotypes, 10 of which were shared (CM-A5, CMA6, CM-A8, CM-A9, CM-A10, CM-A23, CM-A24, CM-A32, CM-A42 and CM-A45) and 4 which were not (CM-A3 and CM-A39, present only at AI, and CM-A25 and CM-A36, present only at CB) (Table 1).
Both areas were characterized by a high predominance of haplotypes CM-A8 (61\% for both areas) and CM-A5 (22 and $20 \%$ for AI and CB, respectively). All remaining haplotypes were present in frequencies $<5 \%$. Rare haplotypes were observed, such as CMA10, CM-A23, CM-A24 and CM-A25, encountered only at Ascension and Rocas/Noronha, CM-A32 only at Rocas Atoll and Ascension and Trindade Islands, CM-A39 and CM-A45 at Ascension Island, and CMA42 in only 2 individuals at the Almofala foraging

Table 1. Chelonia mydas. Haplotype frequencies for study areas and rookeries in the Atlantic, with total number of haplotypes, samples per area, and number of females nesting per year at rookeries. (-): not detected. See Fig. 1 for site abbreviations

\begin{tabular}{|c|c|c|c|c|c|c|c|c|c|c|c|c|}
\hline \multirow{2}{*}{ Haplotypes } & \multicolumn{2}{|c|}{ Study areas } & \multirow[b]{2}{*}{$\mathrm{R} / \mathrm{N}^{\mathrm{c}}$} & \multirow[b]{2}{*}{$\mathrm{TR}^{\mathrm{c}}$} & \multirow[b]{2}{*}{$A S^{d, e, f}$} & \multirow[b]{2}{*}{$\mathrm{GB}^{\mathrm{e}}$} & \multicolumn{2}{|c|}{ Rookeries } & \multirow[b]{2}{*}{$\mathrm{CR}^{\mathrm{g}}$} & \multirow[b]{2}{*}{$\mathrm{MX}^{\mathrm{d}}$} & \multirow[b]{2}{*}{$\mathrm{FL}^{\mathrm{d}}$} & \multirow[b]{2}{*}{$C Y^{\mathrm{d}, \mathrm{l}}$} \\
\hline & $\mathrm{AI}^{\mathrm{a}, \mathrm{b}}$ & $\mathrm{CB}^{\mathrm{b}}$ & & & & & $\mathrm{GG}^{\mathrm{e}}$ & $\mathrm{AV} / \mathrm{SU}^{\mathrm{d}}$ & & & & \\
\hline CM-A1 & - & - & - & - & - & - & - & - & - & 7 & 11 & - \\
\hline $\mathrm{CM}-\mathrm{A} 2$ & - & - & - & - & - & - & - & - & - & - & 1 & - \\
\hline $\mathrm{CM}-\mathrm{A} 3$ & 1 & - & - & - & - & - & - & 3 & 395 & 5 & 12 & - \\
\hline $\mathrm{CM}-\mathrm{A} 4$ & - & - & - & - & - & - & - & - & 1 & - & - & - \\
\hline CM-A5 & 25 & 20 & - & - & - & - & 1 & 40 & 32 & 1 & - & - \\
\hline $\mathrm{CM}-\mathrm{A} 6$ & 2 & 2 & - & - & 11 & - & 6 & 1 & - & - & - & - \\
\hline $\mathrm{CM}-\mathrm{A} 7$ & - & - & - & - & - & - & - & 1 & - & - & - & - \\
\hline $\mathrm{CM}-\mathrm{A} 8$ & 70 & 62 & 50 & 67 & 204 & 70 & 62 & - & - & - & - & - \\
\hline CM-A9 & 5 & 3 & 7 & 19 & 9 & - & - & - & - & - & - & - \\
\hline CM-A10 & 2 & 1 & 2 & - & 5 & - & - & - & - & - & - & - \\
\hline CM-A11 & - & - & 1 & 1 & - & - & - & - & - & - & - & - \\
\hline CM-A12 & - & - & 5 & - & - & - & - & - & - & - & - & - \\
\hline CM-A13 & - & - & - & - & - & - & - & - & - & - & - & 25 \\
\hline CM-A14 & - & - & - & - & - & - & - & - & - & - & - & 1 \\
\hline CM-A 15 & - & - & - & - & - & - & - & - & - & 1 & - & - \\
\hline CM-A16 & - & - & - & - & - & - & - & - & - & 1 & - & - \\
\hline $\mathrm{CM}-\mathrm{A} 17$ & - & - & - & - & - & - & - & - & - & 2 & - & - \\
\hline CM-A18 & - & - & - & - & - & - & - & - & - & 3 & - & - \\
\hline CM-A20 & - & - & - & - & - & - & - & - & 2 & - & - & - \\
\hline CM-A21 & - & - & - & - & - & - & - & - & 3 & - & - & - \\
\hline CM-A23 & 3 & 2 & - & 6 & 1 & - & - & - & - & - & - & - \\
\hline CM-A24 & 3 & 2 & - & 1 & 7 & - & - & - & - & - & - & - \\
\hline CM-A25 & - & 1 & 3 & - & 1 & - & - & - & - & - & - & - \\
\hline CM-A32 & 1 & 3 & 1 & 4 & 1 & - & - & - & - & - & - & - \\
\hline CM-A33 & - & - & - & 1 & - & - & - & - & - & - & - & - \\
\hline CM-A35 & - & - & - & - & - & - & 1 & - & - & - & - & - \\
\hline $\mathrm{CM}-\mathrm{A} 36$ & - & 2 & - & - & - & - & 3 & - & - & - & - & - \\
\hline CM-A37 & - & - & - & - & - & - & 1 & - & - & - & - & - \\
\hline CM-A38 & - & - & - & - & - & - & 2 & - & - & - & - & - \\
\hline CM-A39 & 1 & - & - & - & 1 & - & - & - & - & - & - & - \\
\hline CM-A42 & 1 & 1 & - & - & - & - & - & - & - & - & - & - \\
\hline CM-A44 & - & - & - & - & 1 & - & - & - & - & - & - & - \\
\hline $\mathrm{CM}-\mathrm{A} 45$ & 1 & 2 & - & - & 1 & - & - & - & - & - & - & - \\
\hline $\mathrm{CM}-\mathrm{A} 46$ & - & - & - & - & 2 & - & - & - & - & - & - & - \\
\hline CM-A50 & - & - & - & - & 1 & - & - & - & - & - & - & - \\
\hline No. haplotypes & 12 & 12 & 7 & 7 & 13 & 1 & 7 & 4 & 5 & 7 & 3 & 2 \\
\hline No. samples & 115 & 101 & 69 & 99 & 245 & 70 & 76 & 45 & 433 & 20 & 24 & 26 \\
\hline No. females $\mathrm{yr}^{-1}$ & - & - & $130^{\mathrm{i}}$ & $1000^{\mathrm{j}}$ & $3800^{\mathrm{k}}$ & $2465^{1}$ & $660^{\mathrm{m}}$ & $2067^{n, o}$ & $27346^{p}$ & $1547^{\circ}$ & $759^{\circ}$ & $100^{\mathrm{q}}$ \\
\hline $\begin{array}{l}{ }^{\mathrm{a}} \text { This study, }{ }^{\mathrm{b}} \text { Pro } \\
\text { al. (2005), }{ }^{\mathrm{h}} \text { Kask } \\
{ }^{\mathrm{l}} \text { Catry et al. } \\
{ }^{\mathrm{q}} \text { Broderick et al }\end{array}$ & $\begin{array}{l}\text { et al. } \\
2000), \\
{ }^{*}, \mathrm{~m}^{\mathrm{T}} \mathrm{Tc} \\
02) .{ }^{*} \mathrm{c}\end{array}$ & $\begin{array}{l}\text { 009), } \\
\text { ellini } \\
\text { hás et } \\
\text { lculate }\end{array}$ & $\begin{array}{l}\text { al et al } \\
995), \mathrm{E} \\
10), \mathrm{n} \\
\text { annua }\end{array}$ & (2006), & $\begin{array}{l}\text { et al. } \\
\text { of nest }\end{array}$ & $\begin{array}{l}\text { a et al. } \\
(1996) \\
(1998)\end{array}$ & $\begin{array}{l}\text { 996), } \\
\text { Almeic } \\
\text { oSemi }\end{array}$ & $\begin{array}{l}\text { eFormia e } \\
\text { da et al. } \\
\text { inoff }(200\end{array}$ & $\begin{array}{l}\text { t al. }(200 \\
2011)^{*}, \\
4), \text { pTro }\end{array}$ & $\begin{array}{l}6),{ }^{\mathrm{f}}(20 \\
\text { Broderi } \\
\text { eng \& }\end{array}$ & $\begin{array}{l}\text { 7), }{ }^{9} \mathrm{Bjc} \\
\mathrm{k} \text { et al } \\
\text { ankin }\end{array}$ & $\begin{array}{l}\text { ndal et } \\
(2006), \\
2005)^{*},\end{array}$ \\
\hline
\end{tabular}


ground, with no observations in rookeries. The number of polymorphic sites defining these haplotypes was 19 for both areas, with a maximum of 12 variations distinguishing them.

Haplotype $(h)$ and nucleotide $(\pi)$ diversities of AI $(h=0.5831 \pm 0.0451 ; \pi=0.00246 \pm 0.00176)$ and $\mathrm{CB}$ $(h=0.5857 \pm 0.0501$ and $\pi=0.00251 \pm 0.00178$ ) were extremely similar and in accordance with the average diversities of most compared foraging aggregations as shown in Table 2.

\section{Genetic differentiation}

The exact test of differentiation and AMOVA revealed an overall structuring among foraging areas ( $p<0.001$ for both analyses); however, genetic struc-

Table 2. Chelonia mydas. Haplotype (h) and nucleotide $(\pi)$ diversity estimates \pm SD for all compared foraging aggregations

\begin{tabular}{|c|c|c|}
\hline Foraging ground & $h$ & $\pi$ \\
\hline Arvoredo Island ${ }^{\mathrm{a}, \mathrm{b}}$ & $0.5831 \pm 0.0451$ & $0.0024 \pm 0.0017$ \\
\hline Cassino Beach $^{\mathrm{a}}$ & $0.5857 \pm 0.0501$ & $0.0020 \pm 0.0015$ \\
\hline Ubatuba $^{\mathrm{c}}$ & $0.4460 \pm 0.0556$ & $0.0021 \pm 0.0016$ \\
\hline Rocas/Noronha $^{\mathrm{d}}$ & $0.5887 \pm 0.0911$ & $0.0019 \pm 0.0015$ \\
\hline Almofala ${ }^{\mathrm{c}}$ & $0.7168 \pm 0.0306$ & $0.0067 \pm 0.0039$ \\
\hline Barbados $^{\mathrm{e}}$ & $0.7734 \pm 0.0276$ & $0.0105 \pm 0.0057$ \\
\hline Bahamas $^{\mathrm{f}}$ & $0.3703 \pm 0.0650$ & $0.0066 \pm 0.0038$ \\
\hline Nicaragua $^{g}$ & $0.1831 \pm 0.0621$ & $0.0039 \pm 0.0025$ \\
\hline Floridah $^{h}$ & $0.4855 \pm 0.0668$ & $0.0032 \pm 0.0021$ \\
\hline North Carolina ${ }^{\mathrm{i}}$ & $0.6778 \pm 0.0310$ & $0.0052 \pm 0.0031$ \\
\hline Average & 0.541 & 0.005 \\
\hline \multicolumn{3}{|c|}{ 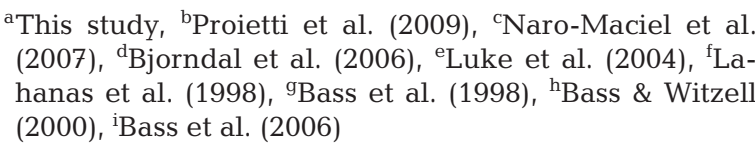 } \\
\hline
\end{tabular}

turing was non-significant between $\mathrm{AI}$ and $\mathrm{CB}$, with a slightly negative $\Phi_{\mathrm{ST}}$ value (Table 3 ). Both analyses revealed that $\mathrm{AI}$ and $\mathrm{CB}$ are genetically different from most areas (Almofala, Nicaragua, Barbados, North Carolina, Florida and Bahamas), but showed no differentiation in relation to Ubatuba and Rocas/ Noronha, both located on the east coast of Brazil (see Table 3).

\section{Surface drifter trajectories and natal origins}

Of the 5842 analyzed drifter tracks, 865 passed through the nesting areas (Table 4). Drifters coming from Ascension and Trindade Islands were dominant at the target area as can be seen in Fig. 2, which illustrates the trajectories of all surface drifters that passed through the eleven $4^{\circ} \times 4^{\circ}$ areas (all rookeries

Table 4. Chelonia mydas. Global drifter data from the Atlantic Ocean and ecological priors for mixed stock analyses. $N=$ total number of drifters per $4^{\circ} \times 4^{\circ}$ area; $Y=$ number of drifters reaching target area of Brazilian coast; $P=$ posterior probability that a drifter that arrived at the target area is from the rookery. Data from Aves Island and Surinam were combined for this analysis

\begin{tabular}{|lrcc|}
\hline Stock & $N$ & $Y$ & $P$ \\
\hline Ascension Island & 56 & 30 & 0.426 \\
Trindade Island & 58 & 30 & 0.412 \\
Rocas/Noronha & 140 & 2 & 0.017 \\
Gulf of Guinea & 45 & 2 & 0.051 \\
Guinea Bissau & 23 & 0 & 0.032 \\
Cyprus & 29 & 0 & 0.025 \\
Costa Rica & 36 & 0 & 0.021 \\
Aves/Surinam & 190 & 0 & 0.004 \\
Mexico & 93 & 0 & 0.008 \\
Florida & 195 & 0 & 0.004 \\
\hline
\end{tabular}

Table 3. Chelonia mydas. Pairwise comparisons of foraging grounds. $\Phi_{\mathrm{ST}}$ values are shown below the diagonal, and p-values for exact tests of differentiation above the diagonal. Non-significant values $(p>0.05)$ in bold. For abbreviations and references for areas see Fig. 1 and Table 2, respectively

\begin{tabular}{|lccccccccccc}
\hline & CB & AI & AF & R/N & UB & NI & BB & NC & FL & BH \\
\hline CB & - & $\mathbf{0 . 9 2 7 9}$ & $<0.001$ & $\mathbf{0 . 6 4 8 7}$ & $\mathbf{0 . 1 2 6 1}$ & $<0.001$ & $<0.001$ & $<0.001$ & $<0.001$ & $<0.001$ \\
AI & $\mathbf{- 0 . 0 0 6 6}$ & - & $<0.01$ & $\mathbf{0 . 7 5 6 8}$ & $\mathbf{0 . 1 5 4}$ & $<0.001$ & $<0.001$ & $<0.001$ & $<0.001$ & $<0.001$ \\
AF & 0.0816 & 0.0724 & - & $<0.05$ & $<0.001$ & $<0.001$ & $<0.001$ & $<0.001$ & $<0.001$ & $<0.001$ \\
R/N & $\mathbf{- 0 . 0 1 0 5}$ & $\mathbf{- 0 . 0 1 1 9}$ & 0.0539 & - & $\mathbf{0 . 5 5 8 6}$ & $<0.001$ & $<0.001$ & $<0.001$ & $<0.001$ & $<0.001$ \\
UB & $\mathbf{0 . 0 0 6 9}$ & $\mathbf{0 . 0 1 1 3}$ & 0.0771 & $\mathbf{- 0 . 0 0 6 5}$ & - & $<0.001$ & $<0.001$ & $<0.001$ & $<0.001$ & $<0.001$ \\
NI & 0.8333 & 0.8221 & 0.6157 & 0.8058 & 0.8276 & - & $<0.001$ & $<0.001$ & $\mathbf{0 . 1 0 8 1}$ & $\mathbf{0 . 3 6 7 4}$ \\
BB & 0.4212 & 0.4144 & 0.1682 & 0.322 & 0.4134 & 0.2941 & - & $<0.001$ & $<0.001$ & $<0.001$ \\
NC & 0.7636 & 0.7564 & 0.5599 & 0.7205 & 0.7575 & 0.0755 & 0.2258 & - & $<0.05$ & $<0.01$ \\
FL & 0.8526 & 0.8408 & 0.6404 & 0.8356 & 0.8464 & $\mathbf{0 . 0 2 1 2}$ & 0.3242 & 0.0334 & - & $<0.05$ \\
BH & 0.7319 & 0.7251 & 0.5149 & 0.6719 & 0.7277 & $\mathbf{0 . 0 1 5 2}$ & 0.1787 & 0.0456 & 0.0503 & - \\
\hline
\end{tabular}




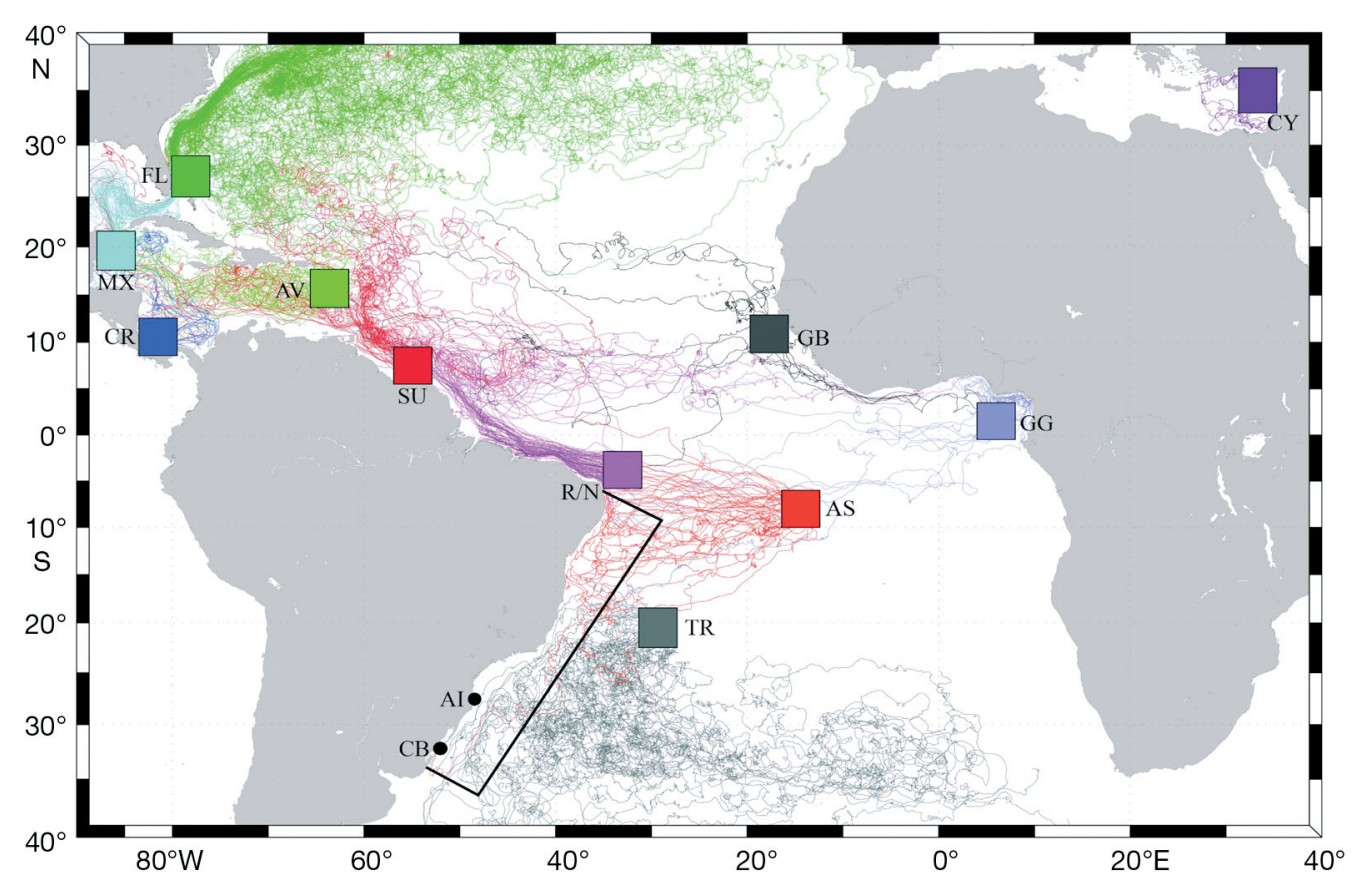

Fig. 2. Chelonia mydas. Surface drifter trajectories (thin lines) in the Atlantic Ocean, with study areas $(\bullet)$, rookeries $\left(4^{\circ} \times 4^{\circ}\right.$, squares), and target area (thick black line). Trajectory color corresponds to rookery color. See Fig. 1 for site abbreviations

considered in the MSAs). Posterior probabilities of origins of drifters that reached the target were $\sim 40 \%$ for Ascension and Trindade, $2 \%$ for Rocas/Noronha and slightly over $5 \%$ for the Gulf of Guinea (Table 4 ). No other rookeries presented drifters that reached the target area.

All MSAs indicated Ascension, Aves/Surinam and Trindade as the main contributors to the $\mathrm{AI}$ and $\mathrm{CB}$ foraging areas (Table 5). Regardless of the used prior, Ascension Island consistently presented the highest mean contributions, ranging from 53.9 to $59.3 \%$.
Estimated contributions from Aves/Surinam varied only slightly between MSAs, and ranged from a mean 21.7 to $22 \%$. Trindade Island also presented significant mean contributions, from 12.7 to $18.2 \%$. Mean contributions varied from 2.4 to $6.3 \%$ for the Gulf of Guinea and were around or lower than $1 \%$ for the remaining rookeries. We highlight that only Ascension and Aves/Surinam presented mean estimates with confidence intervals (CIs) that did not include zero in all MSAs. In $\mathrm{MSA}_{3}$, Trindade's CI also ceased to include zero, but remained large.

Table 5. Mixed stock analyses (MSA) of study areas, with mean rookery contributions (2.5 and $97.5 \%$ CI values in parentheses) and prior weights $(\mathrm{P})$ in $\% . \mathrm{MSA}_{1}=$ uninformative priors; $\mathrm{MSA}_{2}=$ priors weighed according to rookery size (number females $\left.\mathrm{yr}^{-1}\right) ; \mathrm{MSA}_{3}=$ priors weighed according to drifter data; $\mathrm{MSA}_{4}=$ priors weighed according to rookery size/drifter data combined. Data from Aves Island and Surinam were grouped for this analysis

\begin{tabular}{|c|c|c|c|c|c|c|c|c|}
\hline Stock & $\mathrm{MSA}_{1}$ & $\mathrm{P}_{1}$ & $\mathrm{MSA}_{2}$ & $\mathrm{P}_{2}$ & $\mathrm{MSA}_{3}$ & $\mathrm{P}_{3}$ & $\mathrm{MSA}_{4}$ & $\mathrm{P}_{4}$ \\
\hline Ascension & $54.1(33.8-74.8)$ & 10 & $59.3(34.2-80.3)$ & 9.5 & $53.9(34.2-73.1)$ & 42.6 & $58.5(35.8-78.2)$ & 59 \\
\hline Aves/Surinam & $21.7(16.3-27.7)$ & 10 & $21.8(16.2-27.6)$ & 5.1 & $21.8(16.3-27.9)$ & 0.4 & $22(16.5-28.1)$ & 0.4 \\
\hline Trindade & $15.9(0-32.1)$ & 10 & $12.7(0-32.6)$ & 2.5 & $18.2(1.9-35.5)$ & 41.2 & $16.3(0-35.1)$ & 15 \\
\hline Gulf of Guinea & $6.3(0-18.2)$ & 10 & $4.8(0-18.1)$ & 1.6 & $5.6(0-19.4)$ & 5.1 & $2.4(0-15.7)$ & 1.2 \\
\hline Guinea Bissau & $1.5(0-11.8)$ & 10 & $0.9(0-11.4)$ & 6.3 & $0.4(0-5.5)$ & 3.2 & $0.6(0-8.2)$ & 3 \\
\hline Rocas/Noronha & $0.4(0-3.9)$ & 10 & $0.1(0-0.1)$ & 0.3 & $0.1(0-1.1)$ & 1.7 & $0(0-0)$ & 0.1 \\
\hline Costa Rica & $0.1(0-0.8)$ & 10 & $0.5(0-1.9)$ & 68.5 & $0(0-0.2)$ & 2.1 & $0.2(0-1.1)$ & 20.7 \\
\hline Mexico & $0.1(0-0.5)$ & 10 & $0(0-0.3)$ & 4.1 & $0(0-0)$ & 0.8 & $0(0-0)$ & 0.4 \\
\hline Florida & $0.1(0-0.5)$ & 10 & $0(0-0.1)$ & 1.9 & $0(0-0)$ & 0.4 & $0(0-0)$ & 0.1 \\
\hline Cyprus & $0.1(0-0.5)$ & 10 & $0(0-0)$ & 0.2 & $0(0-0.1)$ & 2.5 & $0(0-0)$ & 0.1 \\
\hline
\end{tabular}


The use of different priors did not have substantial effects on posterior contribution estimates, and the used data largely influenced posterior results. Variation of contribution from Aves/Surinam was minimum between MSAs; Ascension and Trindade Island contribution estimates varied in an apparently co-dependent manner in $\mathrm{MSA}_{2}$ and $\mathrm{MSA}_{3}$ : priors rookery size/ drifter data decreased/increased Trindade and increased/decreased Ascension contributions, respectively. Gulf of Guinea's mean contributions varied accordingly to prior weights in all MSAs (see Table 5).

\section{DISCUSSION}

Haplotype frequencies of AI and CB were similar to other Atlantic rookeries and foraging aggregations: high CM-A8 frequency, consistent with the suggestion that this is the closest relative to an ancestral haplotype in the Atlantic basin, followed by a high occurrence of CM-A5, a common haplotype in Caribbean rookeries (Bjorndal et al. 2005, 2006, Formia et al. 2006, 2007, Naro-Maciel et al. 2007), and rare haplotypes. Increasing sample size did not change the proportion of CM-A8 and CM-A5 or the diversity indexes found by Proietti et al. (2009) for green turtles around $\mathrm{AI}_{\text {; }}$ however, the detection of rarer haplotypes increased. This increase could improve resolution of MSA estimates if the rarer haplotypes are also present at a given rookery; however, rare haplotypes may also lead to overestimated contributions from rookeries with uneven sample sizes (Formia et al. 2007). High haplotype and low nucleotide diversities for both study areas followed the general pattern found at other green turtle foraging grounds and are due to mixed characteristic of these areas and small variations between haplotypes, respectively (Bass et al. 2006, Bjorndal et al. 2006, Naro-Maciel et al. 2007).

AI and CB were very similar in terms of haplotype diversity and frequency, and were not significantly different from the Brazilian foraging grounds Ubatuba and Rocas/Noronha. A significant structuring occurs in relation to Almofala, further northwest from Rocas/Noronha. This area presents higher haplotype diversity (see Table 2) with larger frequencies of Caribbean haplotypes, possibly due to its lcation with convergent influence from South Atlantic and Caribbean rookeries. The lack of differentiation between foraging grounds may be due to the coastal migrations, sometimes seasonal, performed by immature sea turtles. Animals may transit between foraging areas depending on factors such as variations in current intensity, water temperature and food availability (Musick \& Limpus 1997, Bass et al. 2006). Avens \& Lohmann (2004) studied displacements of juvenile green turtles in North Carolina, and reported that animals presented seasonal movements in order to stay in warmer waters. This behavior has also been observed in green turtles tagged in Uruguay, which display a pattern of inhabiting lower latitudes in Brazil during colder periods (López-Mendilaharsu et al. 2006). A 4 yr study at AI revealed moderate site fidelity of immature green turtles; however, one turtle tagged at the island was found 6 mo later stranded on a beach at São Paulo state, over $600 \mathrm{~km}$ further north (Reisser et al. 2008). For CB, evidence of residency is not available, and animals at this area present smaller sizes, indicating that it is possibly a recruitment area for post-pelagic animals.

There are 4 green turtle rookeries in central and western South Atlantic Ocean, namely, in decreasing number of nesting females, Ascension Island, Trindade Island, Rocas Atoll and Fernando de Noronha Archipelago (see Fig. 1 for location). Surface drifter trajectories presented in Fig. 2 revealed that Ascension and Trindade Islands, and at a lesser extent the Gulf of Guinea and Rocas/Noronha, present favorable conditions for conducting drifters to the eastern Brazilian coast. Although most authors agree that ocean currents influence sea turtle dispersal and migration, direct evidence exists mainly for post-pelagic animals. Craig et al. (2004) compared the post-nesting migration routes of satellite-tagged female green turtles from Rose Atoll (Pacific Ocean) with surface drifter data and found that migration routes closely paralleled surface ocean currents. Luschi et al. (1998) noted that post-nesting female green turtles satellite-tagged at Ascension Island followed prevailing ocean currents. For satellite-tagged female leatherback turtles Dermochelys coriacea, post-nesting movements were monitored and paralleled to surface drifter data, with the observation that routes were strikingly similar to those of drifters (Luschi et al. 2003b). Although such studies are difficult to perform with hatchling sea turtles and evidence of a passive pelagic stage is mostly indirect, it is reasonable to suspect that ocean currents play an important role in the movements of hatchlings and early juveniles of all sea turtle species. In fact, recent work by Okuyama et al. (2009) visually and radio-tracked the movements of newborn green turtles that had been reared for a variety of days (classified into $1 \mathrm{~d}, 7 \mathrm{~d}$ and 28-56 d age groups) and released into the sea, and demonstrated that ocean surface currents affected turtle migration in all studied age groups. 
As observed in the Brazilian foraging grounds Ubatuba, Almofala (Naro-Maciel et al. 2007) and Rocas/Noronha (Bjorndal et al. 2006, Bolker et al. 2007), the main stock contributing to AI and CB was Ascension Island (Table 5). Naro-Maciel et al. (2007) suggest that Ascension Island hatchlings drift with major Equatorial currents towards South America, while hatchlings from other rookeries may drift away with prevailing currents (see Fig. 1 for the general upper-layer circulation of the Atlantic). For the Gulf of Guinea foraging group, Formia (2002) also found that the highest contributions were from Ascension Island, but followed by almost equal contributions from rookeries located in the Gulf of Guinea. Differently, MSA estimates of a foraging aggregation in North Carolina did not reveal contribution from Ascension, but was composed of individuals from rookeries located in the United States, Mexico and Costa Rica, in accordance with local current patterns and mtDNA structuring of the Caribbean populations (Bass et al. 2006). Aves/Surinam was the second most important contributor to the study areas with estimates remaining essentially the same throughout all MSAs, indicating that the genetic data currently available for this rookery had more influence on results than prior ecological information. High contribution from Aves was not observed for most feeding areas in Brazil, and only Almofala showed a maximum contribution of $18 \%$, a reasonable estimate considering that this area is relatively close to the Aves rookery and composition might be influenced by ocean currents from the Caribbean region. Trindade Island also presented a relatively high contribution $(\sim 13$ to $18 \%)$ in all MSAs. This contribution is higher than results encountered by Bjorndal et al. (2006) and Naro-Maciel et al. (2007) for Almofala, Ubatuba and Rocas/Noronha, and similar to results found by Bolker et al. (2007) for Rocas/Noronha in a many-to-many MSA scenario. The apparent dependency between mean contributions from Ascension and Trindade Islands in $\mathrm{MSA}_{2}$ and $\mathrm{MSA}_{3}$ is probably caused by the somewhat similar haplotype frequencies of these stocks, combined with the fixed results from the other significant contributor, Aves/Surinam. Only $\mathrm{MSA}_{4}$ increased estimates from both stocks, most likely due to the decrease in estimated contribution from Gulf of Guinea. The contribution of African rookeries to Ubatuba and Almofala (NaroMaciel et al. 2007) and Rocas/Noronha (Bjorndal et al. 2006, Bolker et al. 2007) was relatively high $(\sim 10 \%)$, but this estimate was considered flawed by Naro-Maciel et al. (2007) due to the fixed characteristic of Guinea Bissau for haplotype CM-A8. In this work, Gulf of Guinea's contribution to AI/CB was somewhat noticeable in $\mathrm{MSA}_{1}$ and $\mathrm{MSA}_{3}(\sim 6 \%)$. Low contributions from North American rookeries are in accordance with findings for the above-cited feeding areas in Brazil. Contributions from Cyprus were almost null in all MSAs, in accordance with all other studies quoted above, reinforcing the hypothesis that Mediterranean green turtles rarely forage outside this sea (Kaska 2000).

The link between Brazil and Ascension Island has long been disclosed by tagging and telemetry studies of female green turtles (Meylan 1995, Luschi et al. 1998, Hays et al. 2002). There is no direct evidence of movements between Aves Island/Surinam and Brazilian foraging grounds, but other Caribbean rookeries have been shown to be linked to North Brazil (Lima et al. 2008). Marcovaldi et al. (2000) reported frequent recaptures along the Brazilian coast (from latitudes $03^{\circ} 45^{\prime}$ to $20^{\circ} 08^{\prime} \mathrm{S}$ ) of adult female green turtles tagged at Trindade Island, demonstrating that movements between this island and coastal foraging grounds are common. Although green turtles tagged at Trindade have also been recaptured in western Africa (Marcovaldi et al. 2000), transatlantic movements between coastal Brazil and Africa have not yet been confirmed. Despite the scarcity of drifter data for the Gulf of Guinea area, it can be noted that some buoys presented a tendency to drift towards the western Atlantic (Fig. 2). Monzón-Argüello et al. (2010) also verified this tendency through analysis of Lagrangian drifter data, and additionally revealed that the opposite displacement through the North Atlantic is very likely. Godley et al. (2010), integrating satellite tracking, molecular data and particle modeling to understand green turtle migrations in the eastern Atlantic, suggest that Gulf of Guinea stocks are most likely dispersed around tropical West Africa. However, some modeled particles entered the South Equatorial Current and were carried to the Brazilian coast, and we suggest, as do Godley et al. (2010), that further genetic sampling be conducted at the eastern Atlantic in order to include populations currently lacking molecular analyses and improve natal origin estimates of mixed stocks.

Ascension Island's large contribution is in accordance with drifter trajectories, which clearly show that surface currents favor dispersal from this area towards the Brazilian coast. Various authors have demonstrated that a west-southwest flow of the South Atlantic Equatorial Current is a common feature at the Ascension area (Luschi et al. 1998, Hays et al. 2002). Thus, it is reasonable to suggest that hatchlings arrive at the South American coast by means of 
this favorable current. Considering that the nesting female population size influences contribution, Ascension Island is expected to present high contributions as it is the largest of the South Atlantic rookeries, with $~ 3800$ females nesting annually (Broderick et al. 2006).

Few drifters left the Rocas/Noronha area and moved southwards along the eastern Brazilian coast (Fig. 2, Table 4); conditions favor drifting northward along the Brazilian coast due to the strong North Brazil Current. These rookeries together host a small population of nesting females (ca. 100 to 150 ind. $\mathrm{yr}^{-1}$ ) (Bellini et al. 1995, Bellini \& Sanches 1996), which also supports their low estimated contribution. High contributions from Aves/Surinam in all MSAs were not in accordance with drifter data, which showed no link between these rookeries and the eastern Brazilian coast. Despite presenting a large annual nesting population when combined ( 2067 females season ${ }^{-1}$; Seminoff 2004), the geographic distance and relatively few analyzed samples $(n=30$ and 15 for Aves and Surinam, respectively) lead us to believe that mean contributions may be overestimated, and further mtDNA characterization of females should be conducted at the areas. It is however reasonable to assume that some animals foraging at the study areas are indeed from these Caribbean rookeries. Trindade Island is the second largest rookery in the South Atlantic Ocean, with $\sim 1000$ females $\mathrm{yr}^{-1}$ during the last 6 nesting seasons (Almeida et al. 2011). It is also close to the Brazilian coast, and clearly presents favorable ocean currents for arrival at the target area (see Fig. 2); therefore, contribution from this area might be underestimated.

MSA applied to sea turtles presents high standard deviations and is based on the assumption that all sources have been adequately sampled. This is not the case, and many stocks lack genetic studies or are represented by small sample sizes (Avise 2007). All CIs of contributions in this work included zero, reinforcing the uncertainty embedded in this analysis. Also, available mtDNA markers cannot precisely distinguish all rookeries since some haplotypes are common to various stocks. This is the case of the CM08 haplotype, widely distributed in the South Atlantic and considered to be the ancestral haplotype from which others mutated (Formia et al. 2006). Interpretation of results must take this into account by assuming regional origins as opposed to exact nesting beaches (Avise 2007), and further sampling of stocks and analysis of larger mtDNA fragments, as well as additional molecular markers, is highly recommended. Despite these potential biases, MSA can be useful for inferences on green turtle origins in foraging habitats as long as cautiously interpreted (Bowen \& Karl 2007).

An advantage of MSA in a Bayesian framework is the incorporation of previous knowledge as priors. Reproductive data can be extremely useful ecological priors if collected based on standard protocols. Number of nesting females per year is the most commonly available information representing reproductive population size, but this information can sometimes be biased. For example, Bjorndal et al. (2006), Bolker et al. (2007) and Naro-Maciel et al. (2007) followed Seminoff (2002) and considered that 3000 females nest annually at Trindade Island, which is overestimated, as mentioned above. An important consideration when using population size as a prior is the inter-annual variability in numbers of nesting females, which can be influenced by feeding conditions between nesting seasons and recruitment success (Broderick et al. 2001). A solution for this problem could be the long-term collection of standardized reproductive data (estimates of number of females, nests and hatchlings), combined with information on hatchling survival, providing a more accurate estimates of the number of turtles that effectively reach the sea. Another frequently used ecological prior is distance from source to mixture, in the form of great circle linear distances. These distances are the shortest geodesic measure between 2 points and usually do not represent actual travelled distances, especially in light of the mesoscale patterns of ocean currents, with their meanders and eddies. Although CIs were not noticeably narrowed, some differences in mean contributions were found when using drifter data, and they are probably more realistic and informative for MSA than geodesic distances when considering migrations of immature sea turtles.

Some caveats exist in considering surface drifter data as ecological information for green turtles: (1) surface buoys present $15 \mathrm{~m}$ drogues to measure mixed layer currents (Lumpkin \& Pazos 2007) and therefore do not consider surface wind drag, which could influence hatchling movement; (2) data were not limited to the hatching seasons of turtles, due to the large reduction in number of available drifter data; and (3) the life-span of a drifter ( $400 \mathrm{~d}$; see Lumpkin \& Pazos 2007) is usually shorter than the pelagic phase of hatchlings. However, the use of such data has the potential to provide a more thorough understanding of sea turtle dispersal. We recommend that future MSA analyses further advance prior development. This could be done by modeling the afterlife of drifters and considering the effect of 
wind drag on surface currents, or by modeling particle tracks representing passively drifting oceanicphase turtles, as performed in Blumenthal et al. (2009) and Hays et al. (2010). Other information currently being disclosed, such as estimations of the pelagic stage duration through stable isotope ratios and telomere length, and correlation of feeding grounds and rookeries based on stable isotopes and tag returns, can also be considered in prior development.

The insertion of ecological priors somewhat altered MSA means and slightly narrowed CIs for Ascension and Trindade Islands (Table 5). When using rookery size (number of females $\mathrm{yr}^{-1}$ ) as an ecological prior for MSA of Rocas/Noronha, Bjorndal et al. (2006) found a decrease in contributions from Ascension and Aves Islands and an increase in contribution from Trindade. For Ubatuba and Almofala, insertion of the same prior increased contribution estimates from Ascension and Trindade Islands, while the Aves Island contribution decreased (NaroMaciel et al. 2007). However, as mentioned above, these authors used an overestimated rookery size for Trindade Island, and such alterations in stock estimates should be reexamined. Bass et al. (2006) reported changes when incorporating population size in MSA of the North Carolina foraging area, and concluded that the resulting estimates are biologically more meaningful than estimates obtained with uninformative priors. Jensen (2010) compared mark-recapture and MSA estimates of green turtle mixed stocks in the Great Barrier Reef and encountered highest support when using priors weighed according to population size. Natal origins of other sea turtle species are also investigated through MSA with the incorporation of ecological priors, mainly rookery size (e.g. Caretta caretta: Bass et al. 2004, Casale et al. 2008; Eretmochelys imbricata: Velez-Zuazo et al. 2008, Blumenthal et al. 2009). In this work, all priors were taken to be only weakly informative with respect to the data, which helps to explain why $\mathrm{MSA}_{3}$ and $\mathrm{MSA}_{4}$ did not greatly narrow CIs. However, they could be the ideal scenario for obtaining ecologically-realistic stock contribution estimates, and based on Kulback-Leibler distances (Burnham \& Anderson 1998), these distributions are clearly distinct from the non-informative $\mathrm{MSA}_{1}$ and from $\mathrm{MSA}_{2}$, which are close by comparison (see Appendix for details). Exploring alternative statistical approaches to MSA, such as the hierarchical Bayesian model proposed by Okuyama \& Bolker (2005) and the many-to-many analysis described in Bolker et al. (2007), could improve the incorporation and weight assigned to ecological covariates, with larger influence on results.

Mean curved carapace size of sampled animals was smaller in $\mathrm{CB}$ than at $\mathrm{AI}$, which agrees with mean sizes of 40.7 and $50.1 \mathrm{~cm}$ registered by Monteiro et al. (2006) and Reisser et al. (2008) for the 2 areas, respectively. Although genetically similar, these habitats may represent different stages in the life cycles of immature green turtles, and we suggest adoption of local-basis management strategies due this difference. Marine turtle bycatch in fisheries is today one of the major obstacles for the recovery of populations reduced by overexploitation and habitat degradation. In southern Brazil, sea turtle mortality due to fisheries bycatch, as well as ingestion of human debris, is an issue of concern for their conservation (Bugoni et al. 2001, Domingo et al. 2006). Such impacts on the developmental stages ultimately affect later stages, thus the protection of immature animals along the coast leads to the conservation of rookeries that are frequently thousands of $\mathrm{km}$ away (Naro-Maciel et al. 2007). In this work, it was shown with relative certainty that the studied mixed green turtle aggregations originate from rookeries located in different countries. Although Brazil hosts a successful sea turtle conservation project (Projeto Tamar-ICMBio), the fact that green turtles at southern Brazil transpose political/cultural boundaries demonstrates that international cooperation is essential for their conservation. Therefore, the identification of stock contributors to the studied areas has important local and international implications, and should be considered in the formulation of conservation and management strategies.

Acknowledgements. We are thankful to Pata da Cobra Diving, Brazilian Navy and field work personnel for logistic support. Núcleo de Educação e Monitoramento Ambiental (NEMA) and Centro de Recuperação de Animais Marinhos (CRAM) collected samples from Cassino Beach. We thank L. Artico, D. Volcan and A. Studzinsky for laboratorial aid, F. Santos, S. Vargas and the Laboratório de Biodiversidade e Evolução Molecular (UFMG) staff for sequencing; Projeto Tamar-ICMBio for partnership; and M. Mata for insight on drifter analysis. We are also thankful to G. Hays and B. Godley, as well as 4 anonymous reviewers, for valuable suggestions on the manuscript. M.C.P. and J.W.R. were graduate students of the Programa de Pós-graduação em Oceanografia Biológica (FURG) and received scholarships from the Conselho Nacional de Pesquisa (CNPq - Brazil) when the manuscript was prepared. E.R.S. is sponsored by CNPq (PQ 305219/2008-1). Research was conducted thanks to financial support from the Rufford Small Grants (RSG - UK) and the People's Trust for Endangered Species (PTES - UK). This is a contribution of the Research Group 'Ecologia e Conservação da Megafauna Marinha - EcoMega'. 


\section{LITERATURE CITED}

Allard MW, Miyamoto MM, Bjorndal KA, Bolten AB, Bowen BW (1994) Support for natal homing in green turtles from mitochondrial DNA sequences. Copeia 34-41

Almeida AP, Moreira LMP, Bruno SC, Martin AS, Bolten AB, Bjorndal KA (2011) Green turtles nesting on Trindade Island, Brazil. Abstract presented at the 31st Annual Symposium on Sea Turtle Biology and Conservation, San Diego, CA

Avens L, Lohmann KJ (2004) Navigation and seasonal migratory orientation in juvenile sea turtles. J Exp Biol 207:1771-1778

Avise JC (2007) Conservation genetics of marine turtles: ten years later. In: Hewitt $\mathrm{D}$, Fulbright $\mathrm{T}$ (eds) Frontiers in wildlife science: linking ecological theory and management applications. CRC Press, Boca Raton, FL, p 295-314

Bass AL, Witzell WN (2000) Demographic composition of immature green turtles (Chelonia mydas) from the east central Florida coast: evidence from mtDNA markers. Herpetologica 56:357-367

- Bass AL, Lagueux CJ, Bowen BW (1998) Origin of green turtles, Chelonia mydas, at 'Sleeping Rocks' off the northeast coast of Nicaragua. Copeia 1064-1069

> Bass AL, Epperly SP, Braun-McNeill J (2004) Multi-year analysis of stock composition of a loggerhead turtle (Caretta caretta) foraging habitat using maximum likelihood and Bayesian methods. Conserv Genet 5:783-796

Bass AL, Epperly SP, Braun-Mcneill J (2006) Green turtle (Chelonia mydas) foraging and nesting aggregations in the Caribbean and Atlantic: impact of currents and behavior on dispersal. J Hered 97:346-354

Bellini C, Sanches TM (1996) Reproduction and feeding of marine turtles in the Fernando de Noronha Archipelago, Brazil. Mar Turtle Newsl 74:12-13

Bellini C, Marcovaldi MA, Sanches TM, Grossman A, Sales G (1995) Atol das Rocas biological reserve: second largest Chelonia rookery in Brazil. Mar Turtle Newsl 72: 1-2

> Bjorndal KA, Bolten AB, Troeng S (2005) Population structure and genetic diversity in green turtles nesting at Tortuguero, Costa Rica, based on mitochondrial DNA control region sequences. Mar Biol 147:1449-1457

Bjorndal KA, Bolten AB, Moreira L, Bellini C, Marcovaldi MA (2006) Population structure and diversity of Brazilian green turtle rookeries based on mitochondrial DNA sequences. Chelonian Conserv Biol 5:262-268

Blumenthal JM, Abreu-Grobois FA, Austin TJ, Broderick AC and others (2009) Turtle groups or turtle soup: dispersal patterns of hawksbill turtles in the Caribbean. Mol Ecol 18:4841-4853

Bolker BM, Okuyama T, Bjorndal KA, Bolten AB (2007) Incorporating multiple mixed stocks in mixed stock analysis: 'many-to-many' analyses. Mol Ecol 16:685-695

Bolten A (2003) Variation in sea turtle life history patterns: neritic vs. oceanic developmental stages. In: Lutz PL, Musick JA, Wyneken J (eds) The biology of sea turtles, Vol 2. CRC Press, Boca Raton, FL, p 243-257

> Bowen BW, Karl SA (2007) Population genetics and phylogeography of sea turtles. Mol Ecol 16:4886-4907

Boyle MC, FitzSimmons NN, Limpus CJ, Kelez S, VelezZuazo X, Waycott M (2009) Evidence for transoceanic migrations by loggerhead sea turtles in the southern Pacific Ocean. Proc Biol Sci 276:1993-1999
Broderick AC, Godley BJ, Hays GC (2001) Trophic status drives interannual variability in nesting numbers of marine turtles. Proc Biol Sci 268:1481-1487

Broderick AC, Glen F, Godley BJ, Hays GC (2002) Estimating the size of nesting populations of green and loggerhead turtles in the Mediterranean. Oryx 36:227-236

Broderick AC, Frauenstein R, Glen F, Hays GC and others (2006) Are green turtles globally endangered? Glob Ecol Biogeogr 15:21-26

$>$ Bugoni L, Krause L, Petry MV (2001) Marine debris and human impacts on sea turtles in Southern Brazil. Mar Pollut Bull 42:1330-1334

Burnham KB, Anderson DR (1998) Model selection and multimodel inference: a practical information-theoretic approach, 2nd edn. Springer Verlag, New York, NY

Carr AF (1967) So excellent a fishe: a natural history of sea turtles. Scribner, New York, NY

> Carreras C, Pont S, Maffucci F, Pascual M and others (2006) Genetic structuring of immature loggerhead sea turtles (Caretta caretta) in the Mediterranean Sea reflects water circulation patterns. Mar Biol 149:1269-1279

- Casale P, Freggi D, Gratton P, Argana R, Oliverio M (2008) Mitochondrial DNA reveals regional and interregional importance of the central Mediterranean African shelf for loggerhead sea turtles (Caretta caretta). Sci Mar 72: 541-548

Catry P, Barbosa C, Indjai B, Almeida A, Godley BJ, Vie JC (2002) First census of the green turtle at Poilao, Bijagos Archipelago, Guinea-Bissau: the most important nesting colony on the Atlantic coast of Africa. Oryx 36:400-403

Coutinho R, Seeliger U (1984) The horizontal distribution of the benthic algal flora in the Patos Lagoon Estuary, Brazil, in relation to salinity, substratum and wave exposure. J Exp Mar Biol Ecol 80:247-257

Craig P, Parker D, Brainard R, Rice M, Balazs G (2004) Migrations of green turtles in the central South Pacific. Biol Conserv 116:433-438

Domingo A, Bugoni L, Prosdocimi L, Miller P and others (2006) El impacto generado por las pesquerías en las tortugas marinas en el Océano Atlántico sud occidental. WWF Programa Marino para Latinoamérica y Caribe, San José

> Encalada SE, Lahanas PN, Bjorndal KA, Bolten AB, Miyamoto MM, Bowen BW (1996) Phylogeography and population structure of the Atlantic and Mediterranean green turtle Chelonia mydas: a mitochondrial DNA control region sequence assessment. Mol Ecol 5:473-483

Excoffier L, Laval G, Schneider S (2005) Arlequin ver. 3.0: an integrated software package for population genetics data analysis. Evol Bioinform Online 1:47-50

Formia A (2002) Population and genetic structure of the green turtle (Chelonia mydas) in West and Central Africa: implications for management and conservation. PhD thesis, Cardiff University

- Formia A, Godley BJ, Dontaine JF, Bruford MW (2006) Mitochondrial DNA diversity and phylogeography of endangered green turtle (Chelonia mydas) populations in Africa. Conserv Genet 7:353-369

Formia A, Broderick AC, Glen F, Godley BJ, Hays GC, Bruford MW (2007) Genetic composition of the Ascension Island green turtle rookery based on mitochondrial DNA: implications for sampling and diversity. Endang Species Res 3:145-158

Gelman A, Carlin JB, Stern HS, Rubin DB (1995) Bayesian data analysis. Chapman \& Hall/CRC Press, London 
Gelman A, Carlin JB, Stern HS, Rubin DB (2004) Bayesian data analysis, 2nd edn. Chapman \& Hall/CRC Press, London

Godley BJ, Lima EHSM, Åkesson S, Broderick AC and others (2003) Movement patterns of green turtles in Brazilian coastal waters described by satellite tracking and flipper tracking. Mar Ecol Prog Ser 253:279-288

Godley BJ, Barbosa C, Bruford M, Broderick AC and others (2010) Unravelling migratory connectivity in marine turtles using multiple methods. J Appl Ecol 47:769-778

Hamann M, Godfrey MH, Seminoff JA, Arthur K and others (2010) Global research priorities for sea turtles: informing management and conservation in the 21st century. Endang Species Res 11:245-269

> Hays GC, Marsh R (1997) Estimating the age of juvenile loggerhead sea turtles in the North Atlantic. Can J Zool 75: 40-46

> Hays GC, Broderick AC, Godley BJ, Lovell P, Martin C, McConnel BJ, Richardson S (2002) Biphasal long-distance migration in green turtles. Anim Behav 64:895-898

Hays GC, Fossette S, Katselidis KA, Mariani P, Schofield G (2010) Ontogenetic development of migration: Lagrangian drift trajectories suggest a new paradigm for sea turtles. J R Soc Interface 7:1319-1327

Hillis DM, Mable BK, Larson A, Davis SK, Zimmer EA (1996) Nucleic acids IV: sequencing and cloning. In: Hillis DM, Moritz C, Mable BK (eds) Molecular systematics, 2nd edn. Sinauer Associates, Sunderland, MA, p 321-381

Jensen MP (2010) Assessing the composition of green turtle (Chelonia mydas) foraging grounds in Australasia using Mixed Stock Analysis. PhD thesis, University of Canberra

Kaska Y (2000) Genetic structure of Mediterranean sea turtle populations. Turk J Zool 24:191-197

> Lahanas PN, Miyamoto MM, Bjorndal KA, Bolten AB (1994) Molecular evolution and population genetics of Greater Caribbean green turtles (Chelonia mydas) as inferred from mitochondrial DNA control region sequences. Genetica 94:57-66

> Lahanas PN, Bjorndal KA, Bolten AB, Encalada SE, Miyamoto MM, Valverde RA, Bowen BW (1998) Genetic composition of a green turtle (Chelonia mydas) feeding ground population: evidence for multiple origins. Mar Biol 130:345-352

Lee PM, Luschi P, Hays GC (2007) Detecting female precise natal philopatry in green turtles using assignment methods. Mol Ecol 16:61-74

Lima EHSM, Melo MTD, Severo MM, Barata PCR (2008) Green turtle tag recovery further links Northern Brazil to the Caribbean region. Mar Turtle Newsl 119:14-15

López-Mendilaharsu M, Estrades A, Caraccio MN, Calvo V, Hernández M, Quirici V (2006) Biología, ecología y etología de las tortugas marinas en la zona costera uruguaya. In: Menafra R, Rodríguez-Gallego L, Scarabino F, Conde D (eds) Bases para la conservación y el manejo de la costa uruguaya. Vida Silvestre Uruguay, Montevideo, p 247-257

Luke K, Horrocks JA, LeRoux RA, Dutton PH (2004) Origins of green turtle (Chelonia mydas) feeding aggregations around Barbados, West Indies. Mar Biol 144: 799-805

Lumpkin R, Pazos M (2007) Measuring surface currents with Surface Velocity Program drifters: the instrument, its data, and some recent results. In: Griffa A, Kirwan AD, Mariano AJ, Özgökmen T, Rossby T (eds) Lagrangian analysis and prediction of coastal and ocean dynamics. Cambridge University Press, Cambridge, p 39-67

- Luschi P, Hays GC, Del Seppia C, Marsh R, Papi F (1998) The navigational feats of green sea turtles migrating from Ascension Island investigated by satellite telemetry. Proc Biol Sci 265:2279-2284

> Luschi P, Hays GC, Papi F (2003a) A review of long-distance movements by marine turtles, and the possible role of ocean currents. Oikos 103:293-302

> Luschi P, Sale A, Mencacci R, Hughes GR, Lutjeharms JRE, Papi F (2003b) Current transport of leatherback sea turtles (Dermochelys coriacea) in the ocean. Proc Biol Sci 270:S129-S132

Marcovaldi MA, da Silva ACCD, Gallo BMG, Baptistotte C and others (2000) Recaptures of tagged turtles from nesting and feeding grounds protected by Projeto TAMARIBAMA, Brazil. In: Kalb HJ, Wibbels T (eds) Proc 19th Annu Symp Sea Turtle Biol Conserv. NOAA Tech Memo NMFS-SEFSC 443:164-166

Meylan PA (1995) Sea turtle migration: evidence from tag returns. In: Bjorndal KA (ed) Biology and conservation of sea turtles (revised). Smithsonian Institution Press, Washington, DC, p 91-100

Meylan AB, Meylan PA (1999) Introduction to the evolution, life history, and biology of sea turtles. In: Eckert KL, Bjorndal KA, Abreu-Grobois FA, Donnelly M (eds) Research and management techniques for the conservation of sea turtles. IUCN/SSC Marine Turtle Specialist Group Publication no. 4, p 3-5

Miller JD (1997) Reproduction in sea turtles. In: Lutz PL, Musick JA (eds) The biology of sea turtles. CRC Press, Boca Raton, FL, p 51-81

Monteiro D, Bugoni L, Estima S (2006) Strandings and sea turtle fisheries interactions along the coast of Rio Grande do Sul state, Brazil. In: Frick M, Panagopoulou A, Rees AF, K Williams K (eds) Book of abstracts: 26th Annu Symp Sea Turtle Biol Conserv. International Sea Turtle Society, Greece

Monzón-Argüello C, López-Jurado LF, Rico C, Marco A, López P, Hays GC, Lee PLM (2010) Evidence from genetic and Lagrangian drifter data for transatlantic transport of small juvenile green turtles. J Biogeogr 37: 1752-1766

Musick JA, Limpus CJ (1997) Habitat utilization and migration in juvenile sea turtles. In: Lutz PL, Musick JA (eds) The biology of sea turtles. CRC Press, Boca Raton, FL, p 137-163

Naro-Maciel E, Becker JH, Lima EHSM, Marcovaldi MA, Desalle R (2007) Testing dispersal hypotheses in foraging green sea turtles (Chelonia mydas) of Brazil. J Hered 98: 29-39

Okuyama T, Bolker BM (2005) Combining genetic and ecological data to estimate sea turtle origins. Ecol Appl 15: 315-325

Okuyama J, Abe O, Nishizawa H, Kobayashi M, Yoseda K, Arai N (2009) Ontogeny of the dispersal migration of green turtle (Chelonia mydas) hatchlings. J Exp Mar Biol Ecol 379:43-50

Pella J, Masuda M (2001) Bayesian methods for analysis of stock mixtures from genetic characters. Fish Bull 9: 151-167

Posada D (2008) jModelTest: phylogenetic model averaging. Mol Biol Evol 25:1253-1256

Proietti MC, Lara-Ruiz P, Reisser JR, Pinto LS, Dellagostin OA, Marins LF (2009) Green turtles (Chelonia mydas) 
foraging at Arvoredo Island in Southern Brazil: genetic characterization and mixed stock analysis through mtDNA control region haplotypes. Genet Mol Biol 32: 613-618

Reisser JR, Proietti MC, Kinas PG, Sazima I (2008) Photographic identification of sea turtles: method description and validation, with an estimation of tag loss. Endang Species Res 5:73-82

Seminoff JA (2002) 2002 IUCN red list global status assessment: green turtle (Chelonia mydas). IUCN/SSC Marine Turtle Specialist Group, Gland

Seminoff JA (2004) Global status assessment: green turtle (Chelonia mydas). IUCN/SSC Marine Turtle Specialist Group, Gland

Stramma L, England M (1999) On the water masses and mean circulation of the South Atlantic Ocean. J Geophys Res 104(C9):20863-20883

Thompson JD, Gibson TJ, Plewniak F, Jeanmougin F, Higgins DG (1997) The CLUSTAL_X windows interface: flexible strategies for multiple sequence alignment aided by quality analysis tools. Nucleic Acids Res 25: 4876-4882

Tomás J, Godley BJ, Castroviejo J, Raga JA (2010) Bioko: critically important nesting habitat for sea turtles of West Africa. Biodivers Conserv 19:2699-2714

Troëng S, Rankin E (2005) Long-term conservation efforts contribute to positive green turtle Chelonia mydas nesting trend at Tortuguero, Costa Rica. Biol Conserv 121: 111-116

Velez-Zuazo X, Ramos WD, Van Dam RP, Diez CE, AbreuGrobois FA, McMillan WO (2008) Dispersal, recruitment and migratory behaviour in a hawksbill sea turtle aggregation. Mol Ecol 17:839-853

Weijerman ML, van Tienen A, Schouten D, Hoekert WEJ (1998). Sea turtles of Galibi, Suriname. In: Byles R, Fernandez Y (eds) Proc 16th Annu Symp Sea Turtle Biol Conserv. NOAA Tech Memo NMFS-SEFSC 412: 142-144 
APPENDIX 1. Prior probabilities for mixed stock analysis

Four mixed stock analyses (MSAs) were performed considering different 10-dimensional Dirichlet prior distributions with parameters defined over the set of possible sources of hatchlings (i.e. rookeries). All reported priors are 'open-minded' in the sense that they carry information equivalent to a size 1 sampled observation; this is obtained by constraining the sum of parameters to add up to unity. Hence these parameters are probabilities and will be expressed as $P\left(R_{j}\right)$ for rookery $j$. We denote 'uninformative' the prior with equal weights defined on the set of rookeries $\left(\mathrm{MSA}_{1}\right)$, and further included priors weighed according to number of females $\mathrm{yr}^{-1}$ of each source $\left(\mathrm{MSA}_{2}\right)$, surface drifter data $\left(\mathrm{MSA}_{3}\right)$, and a combination of both $\left(\mathrm{MSA}_{4}\right)$.

In $\mathrm{MSA}_{1}$, we assume equal prior probability for all rookeries $\left(R_{j}, j=1, \ldots, 10\right)$, that is: $P\left(R_{j}\right)=1 / 10$. However, this is only a reasonable uninformative prior as long as all rookeries produce a similar total amount of hatchlings.

In $\mathrm{MSA}_{2}$, we try to account for differences among rookeries by considering the probabilities proportional to the number of females nesting per year at each rookery, that is: $P\left(R_{j}\right) \propto N_{j}$.

Since $\sum_{j} P\left(R_{j}\right)=1$ we obtain the prior distribution $P\left(R_{j}\right)=\frac{N_{j}}{\sum_{i=1}^{10} N_{i}}$. This prior is an approximately uniform probability for any hatchling to reach the eastern Brazilian coast, given that the number of hatchlings per female is nearly constant.

Information of oceanographic influence provided by drifters data was summarized as the number of drifters that passed through the possible source area $\left(n_{j,} j=1\right.$, $\ldots, 10)$ and reached the target area $\left(y_{j}\right)$ consisting in the eastern Brazilian coast, from its southernmost limit to the northeastern corner. Given $n_{j}$, and defining $\theta_{j}$ as 'the probability that a drifter passing through a possible source area $\left(R_{j}, j=1, \ldots, 10\right)$ will reach the target area', then, under suitable conditions, for each $R_{j}$, the total number of drifters that reach the target area $y_{j j}$, follows a binomial distribution. We highlight that the count of drifters that left the source areas and reached the target areas was performed considering 11 source areas, but the remainder of the analyses were done with Aves Island and Surinam combined, resulting in 10 possible sources:

$$
p\left(y_{j} \mid \theta_{j}\right)=\operatorname{Bin}\left(y_{j} \mid n_{j}, \theta_{j}\right)=\left(\begin{array}{l}
n_{j} \\
y_{j}
\end{array}\right) \theta_{j}^{Y_{j}}(1-\theta j)^{n_{j}-y_{j}}
$$

In order to obtain a Bayesian point estimate for the probability $\theta_{j}$, and using a uniform distribution between zero and 1 as uninformative prior for $\theta_{j}$, the posterior density is a Beta distribution (Gelman et al. 1995):

$\left.\theta j\right|_{y_{j} \sim \operatorname{Beta}}\left(y_{j}+1, n_{j}-y_{j}+1\right)$

Defining as success any new drifter that reaches the target area, we are interested in the probability that this drifter comes from a given source area $R_{j}$ and denote this probability by $P\left(R_{j} \mid\right.$ success $)$. Bayes' theorem shows how to incorporate this information into $P\left(R_{j}\right)$.

$$
P\left(R_{j} \mid \text { success }\right)=\frac{p\left(\text { success } \mid R_{j}\right) P\left(R_{j}\right)}{p(\text { success })}
$$

Since $P\left(\right.$ success $\left.\mid R_{j}\right)=\theta_{j}$ and $P($ success $)=\sum_{i=1}^{10} \theta i \cdot P\left(R_{i}\right)$, then for prior $\mathrm{MSA}_{1}$, Eq. (A3) is modified to:

$$
P\left(R_{j} \mid \text { success }\right)=\frac{\theta_{j} \frac{1}{10}}{\frac{1}{10} \sum_{i=1}^{10} \theta_{i}}=\frac{\theta_{j}}{\sum_{i=1}^{10} \theta_{i}}
$$

Similarly, if we use the prior $\mathrm{MSA}_{2}$ for $R_{j}$, we obtain:

$$
P\left(R_{j} \mid \text { success }\right)=\frac{\theta_{j} N_{j}}{\sum_{i=1}^{10} \theta_{i} N_{i}}
$$

In Eqs. (A4) \& (A5), $\theta_{j}$ are unknown constants and need to be estimated. We used the posterior mean $\hat{\theta}_{j}=\frac{y_{j}+1}{n_{j}+2}$ as Bayesian point estimates. Hence, this results respectively in our prior distributions $\mathrm{MSA}_{3}$ :

$$
P\left(R_{j} \mid \text { success }\right)=\frac{\frac{y_{j}+1}{n_{j}+2}}{\sum_{i=1}^{10} \frac{y_{i}+1}{n_{i}+2}}
$$

And prior distribution $\mathrm{MSA}_{4}$ :

$$
P\left(R_{j} \mid \text { success }\right)=\frac{N_{j} \cdot \frac{y_{j}+1}{n_{j}+2}}{\sum_{i=1}^{10} N_{j} \cdot \frac{y_{i}+1}{n_{i}+2}}
$$

To compare the difference of information among these 4 proposed priors, we use Kulback-Leibler (KL) information (Burnham \& Anderson 1998). The KL-information is a measure of discrepancy of a proposed distribution with respect to a reference distribution: here arbitrated to be the non-informative distribution $\mathrm{MSA}_{1}$. The prior distribution $\mathrm{MSA}_{2}$ is closest to $\mathrm{MSA}_{1}$ with distance 2.23, while $\mathrm{MSA}_{3}$ and $\mathrm{MSA}_{4}$ are relatively far away with distances 15.28 and 14.07, respectively. Hence, based on KL-information, the drifter data used to define parameters of $\mathrm{MSA}_{3}$ and $\mathrm{MSA}_{4}$ have a substantial impact on shaping these prior distributions. 